\title{
Modelling copper solvent extraction from acidic sulphate solutions using MOC 45
}

\author{
F.J. Alguacil $\left.{ }^{*}\right)$
}

\begin{abstract}
A mathematical model to predict the extraction has been developed for the $\mathrm{Cu}-\mathrm{MOC} 45$ system. The model consists of sets of nonlinear mass action and mass balance equations where the dimerization of the oxime was also considered. The predictive model calculated the equilibrium concentrations from the total oxime concentration, total copper concentration, initial $\mathrm{pH}$ value and the $\mathrm{O} / \mathrm{A}$ volume phase ratio. The model suggests that the extraction of copper can be defined by the existence of two species into the organic solution: $\mathrm{CuR}_{2}\left(K_{\text {ext }}=4.2\right)$ and $\mathrm{Cu}\left(\mathrm{HR}_{2}\right)_{2}\left(K_{\text {ext }}=10,000\right)$. The initial oxime concentration defines the predominancy in the organic solution of both species. . The model can be used to predict copper extraction isotherm as well as copper stripping with sulphuric acid.
\end{abstract}

Keywords: Copper. Solvent extraction. Modelization MOC 45.

\section{Modelización en el sistema de extracción con disolventes $\mathrm{Cu}^{2+}-\mathrm{SO}_{4}^{2-}-\mathrm{H}^{+}-\mathrm{MOC} 45$}

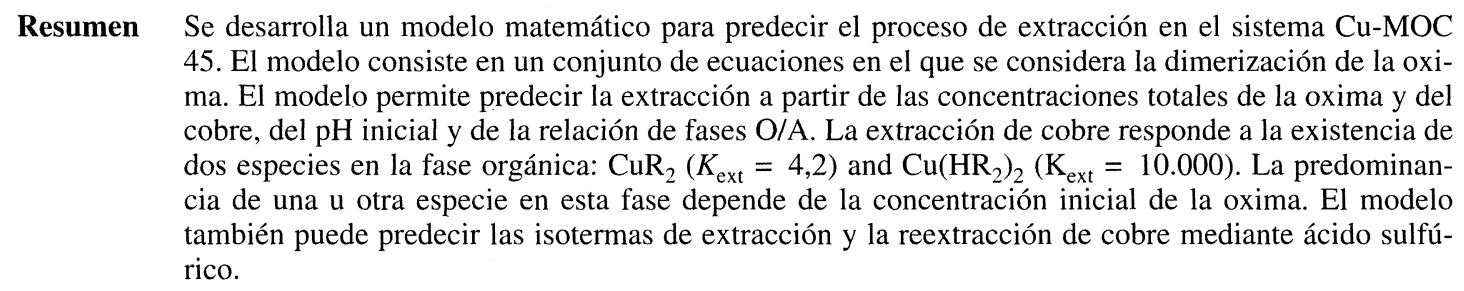

Palabras clave: Cobre. Extracción con disolventes. Modelización. MOC 45.

\section{INTRODUCTION}

Copper production technology saw a drastical change in the late 1960s with the implementation of the solvent extraction-electrowinning circuit as a copper obtention method. The advent of this technology produced the most economical copper in the world, increasing the copper production by this method over the two last decades. Oximes are used for copper extraction in acidic aqueous solutions whereas $\beta$-diketones seem to be favoured in ammoniacal media (1 and 2).

The design of new solvent extraction-electrowinning plants or even the modification of existing ones, usuallys needs of an extensive number of ex-

(*) Centro Nacional de Investigaciones Metalúrgicas, CENIM (CSIC), Avda. de Gregorio del Amo 8. 28040-Madrid. (España). periments until acceptable and efficient operating parameters are obtained.

At this point is where modelling enters in scene. A predictive model can take a number of examples, choose starting conditions and predict with an acceptable degree of accuracy the equilibrium values and thus decreasing the number of preliminary experimentes which otherwise would be required.

Many types of prediction models have been suggested for copper extraction (3-8), at the same time that new oxime extractants are being introduced into the market with, at the present time, few data available on the literature about their performance on copper solvent extraction.

Here a model is presented from which the extraction of copper by the new oxime MOC 45 can be predicted using the starting feed (organic and aqueous streams) conditions. 


\section{EXPERIMENTAL}

The oxime MOC 45 was obtained from the Chilean branch of Allco Chem. and was used as obtained from the manufacturer. The active species of this reagent is the 2-hydroxy-5-nonylacetophenone oxime. As a diluent for the organic phase, kerosene from Campsa (10\% aromatic content) was used.

Stock solutions of copper were prepared by dissolving copper sulphate (AR grade) in water, the $\mathrm{pH}$ value was adjusted to the desired value using $\mathrm{H}_{2} \mathrm{SO}_{4}$ (AR grade).

Copper extraction-stripping experiments were carried out by shaking equal volumes (unless otherwise stated) of the organic and aqueous solutions in separatory funnels, for $20 \mathrm{~min}$ at $20^{\circ} \mathrm{C}$. After phase disengagement, copper was analyzed in the raffinates by AAS, whereas the corresponding acidity was determined by titration with standard $\mathrm{NaOH}$ solution or measuring the equilibrium $\mathrm{pH}$. Copper in the loaded organic solutions was calculated by mass balance. Some copper extraction equilibrium results were taken from the literature (9).

\section{RESULTS AND DISCUSSION}

\subsection{Copper loading by MOC 45}

The loading capacity of MOC 45 was determined contacting $25 \mathrm{~cm}^{3}$ of the organic solution containing $20 \%$ MOC 45 with $25 \mathrm{~cm}^{3}$ of fresh aqueous phase containing $5 \mathrm{~g} / \mathrm{L} \mathrm{Cu}$ at $\mathrm{pH}$ 2.2. A maximum loading of $10.2 \mathrm{~g} / \mathrm{L} \mathrm{Cu}$ was reached after six extraction stages (Fig. 1).

\subsection{The predictive model}

The assumed reactions in building the model are represented by the following equations:

$$
\begin{aligned}
\mathrm{Cu}^{2+}{ }_{\mathrm{aq}}+2 \mathrm{HR}_{\mathrm{org}} & \rightleftarrows \mathrm{CuR}_{2 \mathrm{org}}+2 \mathrm{H}_{\mathrm{aq}}^{+} K_{1} \\
\mathrm{Cu}^{2+}{ }_{\mathrm{aq}}+(\mathrm{HR})_{2 \mathrm{org}} & \rightleftarrows \mathrm{CuR}_{2 \mathrm{org}}+2 \mathrm{H}^{+}{ }_{\mathrm{aq}} K_{2} \\
2 \mathrm{HR}_{\mathrm{org}} & \rightleftarrows(\mathrm{HR})_{2 \mathrm{org}} K_{3}
\end{aligned}
$$

where HR represents the oxime molecule.

The corresponding mass-action equilibrium expressions for the reactions listed above are:

$$
\left[\mathrm{CuR}_{2}\right]_{\mathrm{org}}=K_{1} \frac{\left[\mathrm{Cu}^{2+}\right]_{\mathrm{aq}}[\mathrm{HR}]_{\mathrm{org}}^{2}}{\left[\mathrm{H}^{+}\right]_{\mathrm{aq}}^{2}}
$$

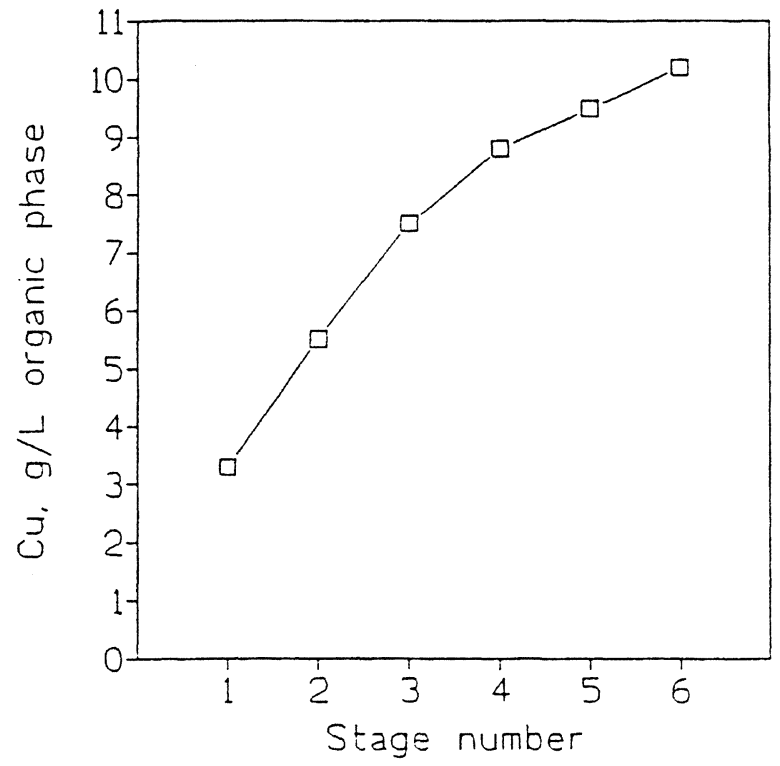

FIG. 1.- Loading capacity of MOC 45 in kerosene in the extraction of copper.

FIG. 1.- Capacidad máxima de carga del MOC 45 disuelto en queroseno en la extracción de cobre.

$$
\begin{gathered}
{\left[\mathrm{CuR}_{2}\right]_{\text {org }}=K_{2} \frac{\left[\mathrm{Cu}^{2+}\right]_{\mathrm{aq}}\left[(\mathrm{HR})_{2}\right]_{\mathrm{org}}}{\left[\mathrm{H}^{+}\right]_{\mathrm{aq}}^{2}}} \\
{\left[(\mathrm{HR})_{2}\right]_{\mathrm{org}}=K_{3}[\mathrm{HR}]_{\mathrm{org}}^{2}}
\end{gathered}
$$

In addition to the above mass-action equations, the model also includes the following mass-balance equations:

$$
\begin{gathered}
{\left[\mathrm{Cu}^{2+}\right]_{\mathrm{t}}=\left[\mathrm{Cu}^{2+}\right]_{\mathrm{aq}}+\mathrm{V}\left[\mathrm{CuR}_{2}\right]_{\mathrm{org}}} \\
{[\mathrm{HR}]_{\mathrm{t}}=[\mathrm{HR}]_{\mathrm{org}}+2{ }_{-}\left[(\mathrm{HR})_{2}\right]_{\mathrm{org}}+2\left[\mathrm{CuR}_{2}\right]_{\mathrm{org}}} \\
{\left[\mathrm{H}^{+}\right]_{\mathrm{aq}}=\left[\mathrm{H}^{+}\right]_{\mathrm{i}}+2 \mathrm{~V}\left[\mathrm{CuR}_{2}\right]_{\mathrm{org}}}
\end{gathered}
$$

where $[\mathrm{Cu}]_{\mathrm{t}}$ is the total copper in the system, $[\mathrm{HR}]_{\mathrm{t}}$ is the total oxime in the system, $\left[\mathrm{H}^{+}\right]_{\mathrm{i}}$ is the hydrogen ion concentration of the aqueous feed solution and $V$ is the organic:aqueous volume ratio. Then all the equilibrium concentrations can be calculated from these parameters.

Furthermore, the experimental data were treated numerically using the program LETAGROPDISTR (10) in order to obtain the values of the extraction constant for the different extracted species. The numerical program minimizes the error-square sum function, $U$, defined as in eq. [10], where $D_{\text {cal }}$ and $D_{\exp }$ are the calculated and experimental values of the distribution coefficient assuming a given chemical model. 
TABLE. I.- Equilibrium constants for the extraction of copper from acidic solutions by MOC 45

TABLA. I.- Constantes de equilibrio para la extracción de cobre en medio ácido por el MOC 45

\begin{tabular}{|c|c|c|}
\hline Species & $\log K_{\text {ext }}$ & $\sigma\left(\log K_{\text {ext }}\right)$ \\
\hline $\mathrm{CuR}_{2}$ & $0.62 \pm 0.08$ & 0.027 \\
$\mathrm{Cu}\left(\mathrm{HR}_{2}\right)_{2}$ & $4.00 \pm 0.07$ & 0.023 \\
\hline
\end{tabular}

$$
U=\Sigma\left(\log D_{\text {cal }}-\log D_{\text {exp }}\right)^{2}
$$

The value of $K_{3}$ for the present model was taken from the literature considering the apparent similarity of MOC 45 and SME 529 extractant (11). Results of the numerical calculation is given in table I.

Figure 2 shows how well the model fits the experimental data over the full range of conditions: MOC $45(0.08 \mathrm{~mol} / \mathrm{L}$ to $0.40 \mathrm{~mol} / \mathrm{L})$, aqueous $\mathrm{pH}$ (0.5 to 3$)$ and copper concentration $(0.60 \mathrm{~g} / \mathrm{L}$ to 15 $\mathrm{g} / \mathrm{L})$.

Figure 3 shows the distribution of the $\mathrm{Cu}-\mathrm{MOC}$ 45 species as a function of the total extractant concentration. The dimer complex is predominant at high oxime concentrations, whereas the monomer complex is predominant at low MOC 45 concentrations.

Additional data were obtained for the present extraction system determining two copper extraction isotherms using $\mathrm{A}: \mathrm{O}$ ratios ranging from 1:10

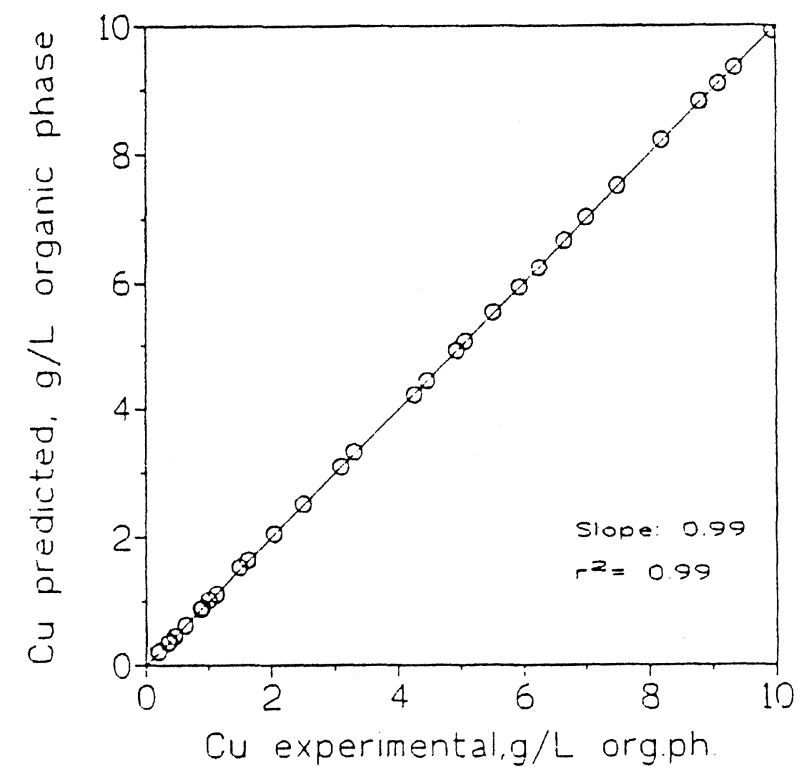

FIG. 2.- Comparison of the copper concentration predicted with the experimental results.

FIG. 2.- Comparación de la concentración de cobre predicha con los resultados experimentales.

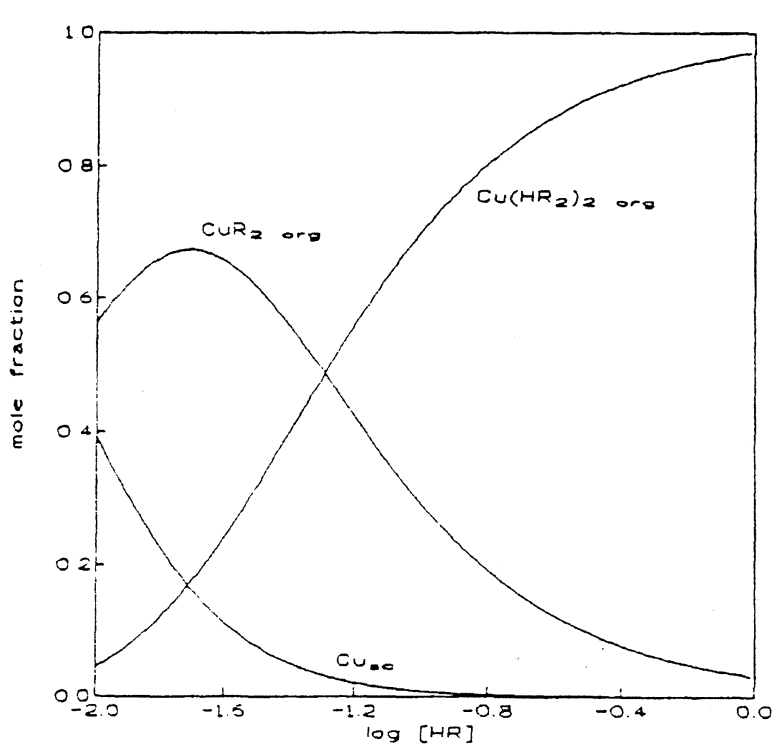

FIG. 3.- Copper distribution diagram as a function of the total oxime concentration. Equilibrium $\mathrm{pH}$, 2.0.

FIG. 3.- 'Diagrama de distribución del cobre en función de la concentración total de oxima. $\mathrm{pH}$ de equilibrio, 2,0.

to $10: 1$ to evaluate the influence of these relationships on the model.

Figure 4 shows the equilibrium curve for the system at various MOC 45 concentrations, whereas in figure 5 the calculated extracted data are compared with the experimental copper extraction values. This last figure shows that the calculated values match the experimental results reasonably well.

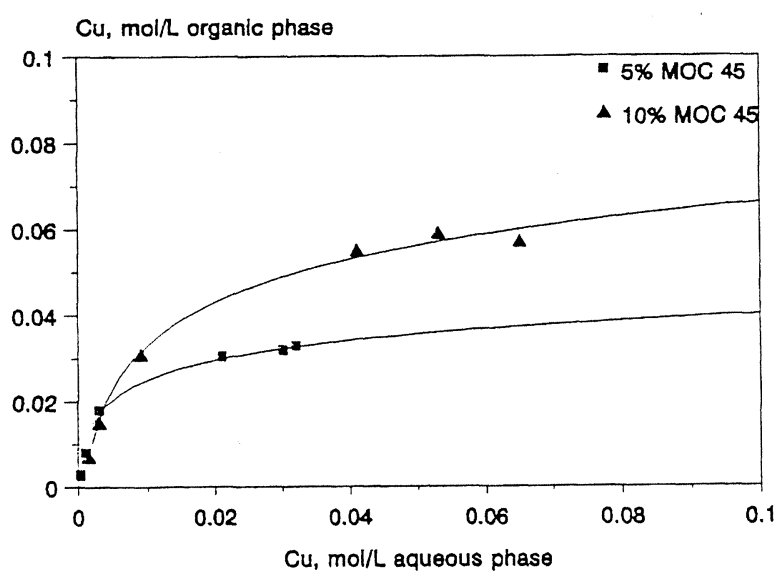

FIG. 4.- Extraction of copper using MOC 45 at differente aqueous-organic phase ratios. Lines show the extraction predicted by the model.

FIG. 4.- Extracción de cobre mediante MOC 45 a distintas relaciones acuoso-orgánico. Las líneas muestran la extracción predicha por el modelo. 


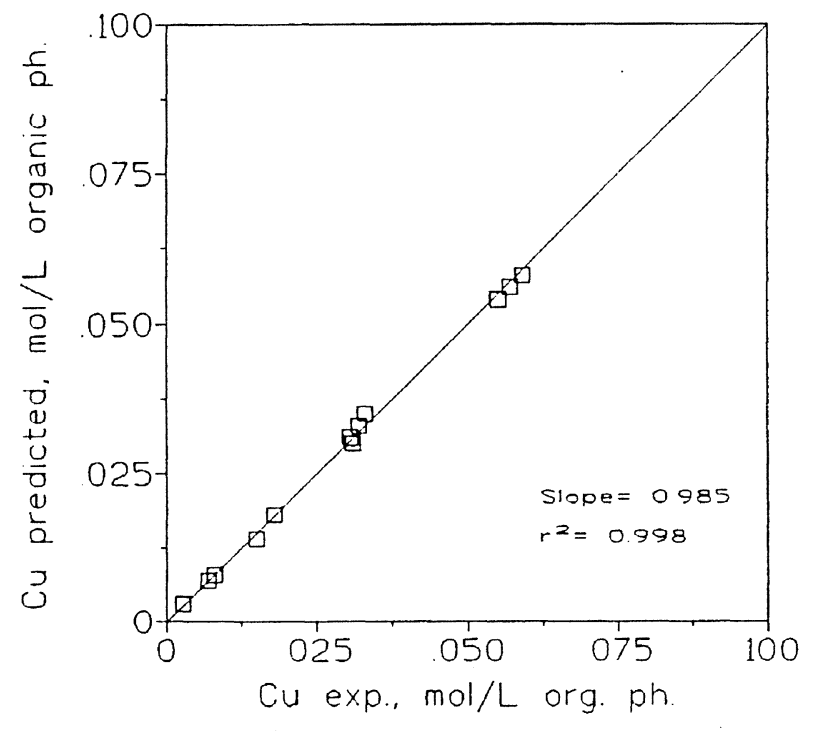

Fig. 5.- Comparison of predicted and experimental copper extraction using MOC 45 at different phase ratios.

Fig. 5.- Comparación de los valores de extracción de cobre predichos y experimentales usando MOC 45 y distintas relaciones de fases.

The model was also used to predict the results of stripping copper-containing organic solutions with different concentrations of sulphuric acid. The organic phase was of MOC $45(0.18 \mathrm{~mol} / \mathrm{L})$ loaded with $3 \mathrm{~g} / \mathrm{L} \mathrm{Cu}$, the sulphuric acid concentration was varied from 10 to $150 \mathrm{~g} / \mathrm{L}$. The model fits the data well as shown in figure 6 .

\section{CONCLUSIONS}

The extraction of copper from acidic sulphate solutions by the commercially available MOC 45 oxime can be predicted by the use of a mathematical model which uses as a starting input the total oxime concentration, the total copper concentration, the initial hydrogen concentration and the O:A phase ratio. The model also predicted reasonably well the extraction of copper at various O:A phase ratios, and hence the obtention of copper extraction isotherms, and the strip of copper using $\mathrm{H}_{2} \mathrm{SO}_{4}$ solutions.

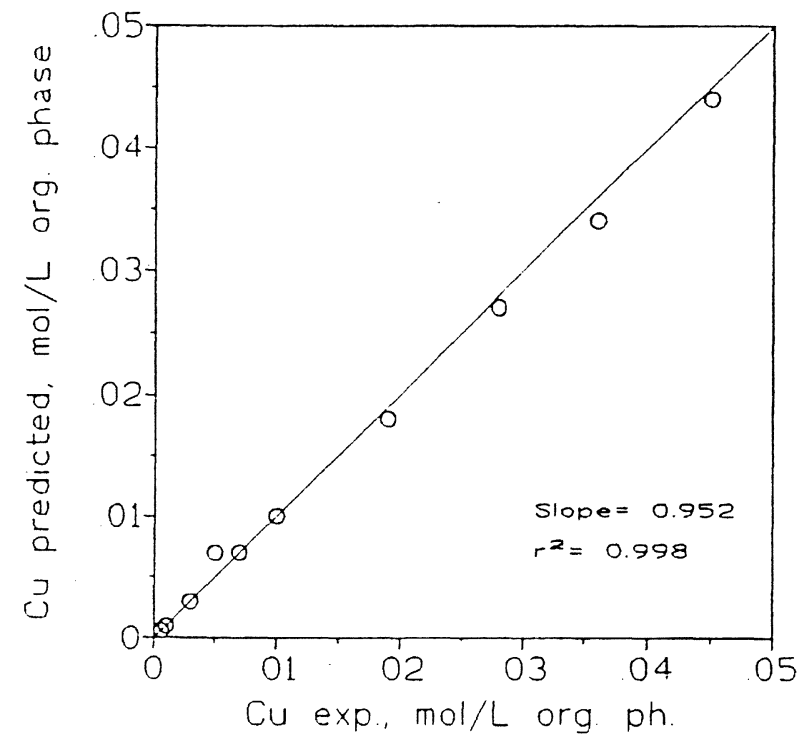

FIG. 6.- Comparison of the predicted copper concentration in the stripped organic phase with experimental results.

FIG. 6:- Comparación de la concentración de cobre en la fase orgánica predicha y experimental en la reextracción de este metal.

\section{REFERENCES}

(1) Cox, M. Principles and Practices of Solvent Extraction, J. Rydberg, C. Musikas and G.R. Choppin. Marcel Dekker. New York. 1992: 357.

(2) Szymanowski, J. Hydroxyoximes and Copper Hydrometallurgy, CRC Press. Boca Raton. 1993, 367.

(3) Forrest, G. and Hughes, M.A. Hydrometallurgy. 1, 1975: 139.

(4) Hoh, Y.-C. and Bautista, R.G. Metall. Trans. B. 9, 1978: 69.

(5) Whewell, R.J. and Hughes, M.A. Hydrometallurgy. 9, 1979: 109.

(6) Szymanowski, J. and Atamanczuk, B. Hydrometallurgy. 9, 1982: 29.

(7) LeE, C.K. and Tavlarides, L.L. Metall. Trans. B. 14, 1983: 153

(8) Piotrowicz, J. and Wasylkiewicz, S. Proc. ISEC'86, 1986: 205.

(9) Amores, M., Coedo, A.G. and Alguacil, F.J. Hydrometallurgy. 47, 1997: 99.

(10) LIEM, D.H. Acta Chem. Scand. 25, 1971: 1.521.

(11) Inoue, K. and Tsunomachi, H. Hydrometallurgy, 13, 1984: 73. 